\title{
Rehabilitating Enemies of Mankind: An Exploration of the Concept of Rehabilitation as a Sentencing Aim at the ICTY and the ICC
}

\author{
Edith Riegler \\ Leiden University, Leiden, The Netherlands \\ e.riegler@umail.leidenuniv.nl
}

\begin{abstract}
This article explores the concept of rehabilitation as a sentencing aim at the International Criminal Tribunal for the former Yugoslavia (ICTY) and the International Criminal Court (ICC). All sentencing decisions and early release decisions, as well as the positive law of the ICTY and the ICC were examined alongside relevant scholarly literature to explore the institutions' conceptualisation of rehabilitation. The comparative qualitative analysis showed that there is considerable incoherence in the conceptualisation of rehabilitation, both within the ICTY, as well as between the ICTY and the ICC. At the ICTY, rehabilitation holds a negligible role within the judgments, yet, paradoxically, evidence of successful rehabilitation is a requirement for early release. The comparison between the sentencing decisions and early release decisions of the ICTY with those of the ICC demonstrated that the focus has shifted from rehabilitating individual perpetrators to reconciling communities.
\end{abstract}

\section{Keywords}

rehabilitation - sentencing - early release - International Criminal Tribunal for the former Yugoslavia (ICTY) - International Criminal Court (ICC)

The Nuremberg and Tokyo Tribunals heralded the beginning of an international endeavour to bring to justice the perpetrators of the most egregious 
violations of international humanitarian law - enemies of mankind. ${ }^{1}$ Even though a sentencing jurisprudence of international criminal law has been developing out of the legacy of the Nuremberg and Tokyo Tribunals, and more prominently, based on the decisions handed down by the International Criminal Tribunal for the former Yugoslavia (ICTY) and the International Criminal Tribunal for Rwanda (ICTR) - henceforth referred to as 'the Tribunals' - a coherent international sentencing framework has not yet been established. ${ }^{2}$ Indeed, the Trial Chambers of the Tribunals, as well as the International Criminal Court (ICC) enjoy wide discretion in relation to the determination of sentences; there are no formal guidelines, as there are in many domestic jurisdictions, and judges are not obliged to follow precedent. ${ }^{3}$ It is striking that, while the prosecution and the trial phase are meticulously governed by various positive law instruments, 'the sanction imposed on offenders still may be little more than an afterthought to the closure purportedly obtained by the conviction' ${ }^{4}$ This is reflected in the judgments, which often span several hundreds of pages, yet feature only cursory remarks that could elucidate the rationales behind the sentencing decisions.

The Tribunals were established by the United Nations Security Council in an effort to set the historical record of the crimes and to contribute to peace, security, and reconciliation in the former Yugoslavia and Rwanda. ${ }^{5}$ However, the concrete objectives that are to be achieved by sentencing perpetrators of international crimes are not explicitly stated in the positive law of the Tribunals or the ICC, though the Preamble to the Rome Statute vaguely implies deterrent, retributive, and expressive aims. ${ }^{6}$ Similarly, the sentencing aims that are irregularly mentioned in the case-law of the Tribunals and the ICC are an

1 James Meernik and Kimi Lynn King, 'The effectiveness of international law and the ICTY preliminary results of an empirical study', 1 International Criminal Law Review (2001) 343-372. For a discussion on the history of the term 'enemies of mankind' and its relevance to international human rights law, see Stephen C. McCaffrey, Understanding International Law (Lexis Nexis, San Francisco, CA, 2006); and Jenny S. Martinez, Hostis Humani Generis: Enemies of Mankind', in Jenny S. Martinez (ed.), The Slave Trade and the Origins of International Human Rights Law (Oxford Scholarship Online, New York, 2015).

2 Mark A. Drumbl, Atrocity, Punishment, And International Law (Cambridge University Press, Cambridge, 2007); William A. Schabas, 'Sentencing by international tribunals: A human rights approach', 7 Duke Journal for Comparative and International Law (1997) 461-517.

3 Mirco Bagaric and John R. Morss, 'International sentencing law: In search of a justification and coherent framework', 6 International Criminal Review (2006) 191-255.

4 Mark A. Drumbl, 'Collective violence and individual punishment: The criminality of mass atrocity', 99(2) Northwestern University Law Review (2005) 549.

5 United Nations Security Council, Resolution 827 (1993) (S/RES/827 (1993)); United Nations Security Council, Resolution 955 (1994) (S/REs/955 (1994)).

6 ICC, Rome Statute of the International Criminal Court (last amended 2010), paras. 3-5. 
amalgamation of deterrence, retribution, rehabilitation, and to a lesser extent, reconciliation. An empirical study has found that the Tribunals' judgments most frequently cite the aims of retribution and deterrence, followed by rehabilitation. ${ }^{7}$ However, the objective of rehabilitation manifests most prominently in the decisions to commute sentences and release perpetrators before the entirety of their sentence has been served. The fact that rehabilitation is not defined anywhere in the positive law or in the case-law of the Tribunals and the ICC, means that a myriad of factors may be considered to indicate signs of successful or unsuccessful rehabilitation when deciding on the appropriateness of early release. ${ }^{8}$

Research is scarce with regard to sentencing aims in international criminal law in general, and the aim of rehabilitation in particular. Some researchers have given attention to the Tribunals' approach to rehabilitation ${ }^{9}$ and some cursory remarks have been made on the role of rehabilitation at the ICc. ${ }^{10}$ However, to the author's knowledge, no work has yet analysed and compared rehabilitation as a sentencing aim at the Tribunals versus the ICc. Early release decisions at the ICTY and ICTR up to 2017 and 2013, respectively, have been systematically analysed in the literature; ${ }^{11}$ however, examination of early

Barbora Holá, Joris van Wijk and Jessica Kelder, 'Effectiveness of International Criminal Tribunals: Empirical Assessment of Rehabilitation as Sentencing Goal', in Nobuo Hayashi and Cecilia M. Baillet (eds.), The Legitimacy of International Criminal Tribunals: Studies on International Courts and Tribunals (Cambridge University Press, Cambridge, 2017), pp. $351^{-} 375$.

8 At the ICTY, such decisions are commonly referred to as 'decisions on early release', 'decisions on sentence remission', or 'decisions on commutation of sentence', while at the ICC the language of 'review concerning reduction of sentence' has been used. For all intents and purposes, these different wordings are interchangeable and refer to equivalent documents. The present article will use 'early release decisions' to cover all such documents.

See Holá, van Wijk and Kelder, supra note 7; Barbora Holá, Joris van Wijk, Francesca Constantini and Armi Korhonnen, 'Does remorse count? ICTY convicts' reflections on their crimes in early release decisions', 28(4) International Criminal Justice Review (2018) 349-371.

10 Andrew Merrylees, 'Two-thirds and you're out? The practices of early release at the ICTY and ICC, in light of the goals of international criminal justice', 8(2) Amsterdam Law Forum (2016) 69-76; Jonathan H. Choi, 'Early release in international criminal law', 123(6) Yale Law Journal (2014) 1784-1828.

11 See Jessica M. Kelder, Barbora Holá and Joris van Wijk, 'Rehabilitation and early release of perpetrators of international crimes: A case study of the ICTY and ICTR', 14 International Criminal Review (2014) 1177-1203; which shows in its analysis of early release decisions at the ICTY and ICTR up to 2013 that the factors that have been noted by the President as relevant to this decision are: "(i) the convict's period in prison, (ii) his/her future perspectives, (iii) his/her reflection on crimes and (iv) his/her personal characteristics"; with the most commonly cited factor being conduct in prison. See also, Holá, van Wijk, Constantini 
release at the ICC has been scarcer, perhaps because only two convicts have been eligible to apply for early release thus far. ${ }^{12}$ To the author's knowledge, there has been no comprehensive analysis yet of the practice of early release at the ICC, in light of the sentencing aim of rehabilitation, or in comparison with the Tribunals' practice. A sound conceptualisation of sentencing aims is a critical component of a coherent sentencing framework. The last two decades have seen a proliferation of international criminal tribunals and hybrid tribunals and it is plausible that further such tribunals will be established in the future. It is crucial to the legitimacy of these institutions and the field of international criminal law at large to employ coherent and well-substantiated normative sentencing frameworks. This study aimed to examine the conceptualisation of rehabilitation as a sentencing aim at the ICTY and the ICC. The article will confine its analysis to these two institutions and will forego the cases of the ICTR due to the limited capacity of this study. Some conclusions of the present study regarding the ICTY may equally apply to the ICTR, as the ICTR resembles the ICTY both in its positive law and in the decisions of the Trial Chambers, which frequently cross-reference one another in their judgments and moreover, shares an Appeals Chamber with the ICTY. However, further research is needed to confirm this notion, as it is plausible that rehabilitation has a different standing at the ICTR, in part because this court has meted out considerably more sentences of life imprisonment than the ICTY. ${ }^{13}$

The data that form the basis of analysis for this research have been extracted primarily from the trial judgments and sentencing decisions, appeals judgments and early release decisions of the ICTY (or alternatively, the International Residual Mechanism for Criminal Tribunals (MICT), which has resumed the work of the ICTY in 2013) and the ICC. ${ }^{14}$ As of the time of writing (December

and Korhonnen, supra note 9, for an empirical investigation of convicts' attitudes towards their crimes and assessments of rehabilitation within ICTY early release decisions.

12 See Choi, supra note 10; and Merrylees, supra note 10 for commentary on the practice of early release at the ICC.

13 Barbora Holá, Allette Smeulers and Catrien Bijleveld, 'International sentencing facts and figures', 9(2) Journal of International Criminal Justice (2011) 411-440. The comparatively longer sentences at the ICTR, including more sentences of life imprisonment, are explained by the higher number of convictions for genocide than at the ICTY. Genocide, considered the gravest of the core crimes, consistently leads to the highest sentences, see Joseph W. Doherty and Richard H. Steinberg, 'Punishment and policy in international criminal sentencing: An empirical study', 110(1) American Journal of International Law (2016) 49-81.

14 At the ICTY, sentencing decisions are mostly encompassed within the trial judgments (except for cases where the defendant enters a guilty plea), whereas at the ICC sentencing decisions are separate documents. 
2019) the ICTY has sentenced go individuals, while the ICC has sentenced five individuals thus far..$^{15} \mathrm{~A}$ spreadsheet was created to systematically collect salient details of all these case documents; primarily, any references to sentencing aims in general, and rehabilitation in particular, were noted down in the spreadsheet to facilitate comparison. In addition, the applicable positive law, namely the Statutes and Rules of Procedure and Evidence (RPE) of the ICTY ${ }^{16}$ and the ICC $^{17}$ were consulted to further inform a comparative qualitative analysis. Data from these various sources have then been summarised alongside relevant scholarly literature, to explore the conceptualisation of rehabilitation across these two institutions.

This article will first examine general principles of sentencing in international criminal law, as well as theoretical discussions of sentencing goals in general and the goal of rehabilitation in particular, including its relevance for early release. This will be followed by an exploration of the conceptualisation of rehabilitation at the ICTY across sentencing decisions and early release decisions. Subsequently, this conceptualisation of rehabilitation at the ICTY will then be contrasted with the sentencing decisions and early release decisions of the ICC to track the development of the concept. The article will conclude with an assessment of the role and meaning of rehabilitation as a sentencing aim at the ICTY as compared to the ICC.

\section{International Sentencing}

As mentioned above, international sentencing is devoid of a concrete sentencing framework and the only guidance can be found in Article 24(2) of the ICTY Statute and Article 78(1) of the Rome Statute that advise that the judges 'should take into account such factors as the gravity of the offence and the individual circumstances of the convicted person'. Crime gravity is deemed to merit the most important consideration and 'may be regarded as the litmus test' for sentence determinations. ${ }^{18}$ However, notably, international criminal law doctrine also allows that factors relating to the individual circumstances of the perpetrator are considered at sentencing; the individual circumstances are

15 For the ICC, this includes the sentencing decisions for Jean-Pierre Bemba Gombo (ICC01/05-01/08), who was acquitted by the Appeals Chamber on 8 June 2018, and Bosco Ntaganda (ICC-01/04-02/06), whose verdict is subject to appeals at the time of writing.

16 ICTY Rules of Procedure and Evidence (IT/32/Rev.50) 8 July 2015.

17 ICC Rules of Procedure and Evidence (ISBN No. 92-9227-278-0) 2013.

18 ICTY, Prosecutor v. Mucić et al., Case No. IT-96-21-Tbis-Ru17, Trial Chamber, Sentencing Judgment, 9 October 2001, para. 1225. 
'represented primarily by mitigating factors.' ${ }^{19}$ Indeed, the ICTY RPE necessitate that aggravating and mitigating circumstances are taken into account however, apart from 'substantial cooperation with the Prosecutor' as a mitigating factor, no other factors are specified. ${ }^{20}$ Within ICTY judgments, the most frequently cited mitigating factor is family circumstances; other factors commonly taken into account by the Trial Chamber are assistance to victims, voluntary surrender, cooperation with the prosecution, guilty plea, remorse, absence of prior crimes, prior good character and good conduct in detention. ${ }^{21}$ In comparison to the Tribunals, the ICC RPE contain somewhat more guidance and posit a limited number of non-exhaustive aggravating and mitigating factors that may be taken into account, ${ }^{22}$ which mirror what the Trial and Appeals Chambers of the Tribunals have developed in case-law. ${ }^{23}$ While aggravating and mitigating factors are never explicitly linked to the sentencing goals, ${ }^{24}$ aggravating factors are more related to the goals of retribution and deterrence, while mitigating factors are thought inter alia to indicate positive rehabilitation prospects. ${ }^{25}$ For example, the accused's good character prior to the conflict could be considered a mitigating factor, as this is arguably related to positive prospects with regard to rehabilitation. ${ }^{26}$

\subsection{Aims of International Sentencing}

In addition to a broad discretion on part of the Trial Chambers to determine sentences, they are also unfettered to stipulate various aims the sentences should pursue. There is no requirement for elaboration on whether the enforcement of the sentences is able to achieve their stated goals nor on the mechanisms that are supposed to effectuate the achievement thereof. ${ }^{27}$ Retribution is considered the leading sentencing consideration in international sentencing. ${ }^{28}$ Modern conceptions of retribution emphasise the principle of proportionality, i.e. that the amount of punishment is proportional to the

\footnotetext{
19 Holá, Smeulers and Bijleveld, supra note 13, p. 415.

20 ICTY RPE, Rule 101(B).

21 Holá, Smeulers and Bijleveld, supra note 13, pp. 411-439.

22 ICC RPE, Rule 145(2).

23 Drumbl, supra note 4.

24 Bagaric and Morss, supra note 3.

25 Doherty and Steinberg, supra note 13.

26 Shahram Dana, 'Revisiting the Blaškić sentence: Some reflections on the sentencing jurisprudence of the ICTY', 4 International Criminal Law Review (2004) 321-348.

27 Adrian Hole, 'The sentencing provisions of the International criminal Court', 1(1) International Journal of Philosophical Studies (2005) 37-69; Bagaric and Morss, supra note 3.

28 Mark B. Harmon and Fergal Gaynor, 'Ordinary sentences for extraordinary crimes', 5(3) Journal of International Criminal Justice (2007) 683-712.
} 
harm caused, ${ }^{29}$ however, proportionality becomes a problematic concept in the context of international crimes, since faced with perpetrators of grave atrocities it is nigh impossible to have any semblance of actual proportionality. ${ }^{30}$ Deterrence is a prominent sentencing aim, though the judgments frequently emphasise that it should not be granted too much weight relative to retribution. The challenge in discussing the utility of deterrence as a sentencing goal is the sheer impossibility of assessing the counterfactual and extracting the independent effect of a penalty on non-criminal behaviour. ${ }^{31}$ The sentencing goal of reconciliation purports that sentencing and bringing to justice the orchestrators of the atrocities can address the plight of those communities that have suffered at the hands of the perpetrators. ${ }^{32}$ Conceptual and operational problems exist with regard to all of these various sentencing aims and there is a lack of clarity in how they are supposed to be achieved; however, these issues become especially apparent with regard to the sentencing aim of rehabilitation, as this concept in particular becomes relevant again when decisions on early release are to be made.

\subsection{The Sentencing Aim of Rehabilitation}

Rehabilitation is a sentencing objective in many ordinary criminal justice systems but a precise definition in the literature is lacking - this is true for the domestic, as well as the international context. ${ }^{33}$ The ultimate goal of rehabilitation is to decrease recidivism, through fundamentally changing internal norms and attitudes of the offender and transforming him or her into a noncriminal and productive member of society. ${ }^{34}$ Rehabilitation should signify both a regression to the state pre-offending, but also a progression to a preferable state; 'rehabilitation is understood as a process of getting back to

29 Pascale Chifflet and Gideon Boas, 'Sentencing coherence in international criminal law: The cases of Biljana Plavšić and Miroslav Bralo', 23 Criminal Law Forum (2012) 135-159.

30 Allison M. Danner, 'Constructing a hierarchy of crimes in international criminal law sentencing', 87(3) Virginia Law Review (2001) 415-501.

31 Stuart Beresford, 'Unshackling the paper tiger - the sentencing practices of the ad hoc international criminal tribunals for the former Yugoslavia and Rwanda', 1 International Criminal Law Review (2001) 33-90; Kate Cronin-Furman, 'Managing expectations: International criminal trials and the prospects for deterrence of mass atrocity', 7 The International Journal of Transitional Justice (2013) 434-454.

32 Bagaric and Morss, supra note 3; Chifflet and Boas, supra note 29.

33 Peter Raynor and Gwen Robinson, Rehabilitation, Crime and Justice (Palgrave Macmillan, Basingstoke, 2009); Francis A. Allen, 'Criminal justice, legal values and the rehabilitative ideal', 5o Journal of Criminal Law, Criminology and Political Science (1959) p. 226.

Bagaric and Morss, supra note 3. 
normal". ${ }^{35}$ The rehabilitative ideal refers to the notion that offending is rooted in certain social or psychological causes that can be identified and that these individual criminogenic factors can be addressed with specific targeted interventions. ${ }^{36}$ Rehabilitative programmes in the ordinary criminal justice context can encompass a variety of objectives, such as focusing on education, employment skills, social skills, psychiatric treatment, drug use treatment, etc. ${ }^{37}$ Underlying this rehabilitative ideal is the acknowledgment that the vast majority of prisoners will eventually return to civil society, hence it is in society's best interest to affect some change in the convicted person so that he or she will be less likely to commit any further offences. ${ }^{38}$ This is equally true for international prisoners, as most are not serving life sentences but 'merely' a few years before they return to society. ${ }^{39}$ In domestic circumstances, it has not yet been established empirically that punishment can effectively achieve rehabilitation, which would be evidenced by lowered rates of re-offending. ${ }^{40}$ In the context of international criminal justice, the role of rehabilitation is, predictably, an even more vexed question and it is difficult to envision what rehabilitation should entail exactly and how it should be achieved.

Those convicted by the ICTY and the ICC are dispersed in a number of states that enforcement agreements have been concluded with ${ }^{41}$ and housed amongst the general prison population..$^{42}$ The prison regime is proscribed by the laws of the enforcement states and the supervision of the sentences and any rehabilitative endeavours are delegated to the specific prisons..$^{43}$ Rehabilitative endeavours with regard to international convicts present with some pertinent challenges; some are related to language barriers, visits from and contact with family members, as well as reintegration into the society of their country of origin. ${ }^{44}$ In addition, evidence-based rehabilitation programmes that are tailored to the special character of international perpetrators do not exist and besides, international prisoners might likely not even benefit from

35 Raynor and Robinson, supra note 33, p. 3.

36 Allen, supra note 33; Beresford, supra note 31; see also Tony Ward and Shadd Maruna, Rehabilitation: Beyond the Risk Paradigm (Routledge, Abingdon, 2007).

37 Holá, van Wijk and Kelder, supra note 7.

38 Stanley E. Grupp, 'Introduction', in Stanley E. Grupp (ed.), Theories of Punishment (Indiana University Press, Bloomington, 1971) pp. 3-12.

39 Holá, van Wijk and Kelder, supra note 7.

$40 \quad$ Bagaric and Morss, supra note 3.

41 ICTY Statute, Art. 27; ICC Statute, Art. 103.

42 Barbora Holá and Joris van Wijk, 'Life after conviction at International Criminal Tribunals: An empirical overview', 12 Journal of International Criminal Justice (2014) 109-132.

43 Meernik and King, supra note 1.

44 Kelder, Holá and van Wijk, supra note 11. 
generic rehabilitative programmes. Perpetrators of international crimes are said to differ from 'ordinary' criminals in a myriad of ways, owing to the extraordinary aetiology of collective violence and mass atrocities, ${ }^{45}$ and often presented as non-deviant and well-adjusted citizens before the commission of crimes. ${ }^{46}$ Therefore, it is hardly surprising that while a considerable part of the regular prison population may consist of volatile, poorly adjusted, impulsive or deviant individuals, perpetrators of international crimes usually exhibit excellent conduct in prison. ${ }^{47}$ It stands to reason that they will likely not commit any violent crimes again, not to speak of international crimes, especially when the toxic political and social circumstances have dissipated and the region where collective violence had taken place has regained relative peace. ${ }^{48}$

\subsection{Rehabilitation and Early Release}

When and if a person convicted by the ICTY becomes eligible for early release is also determined by the enforcement states, ${ }^{49}$ at which point the prisoner or the enforcement state may apply to the President of the Tribunal. ${ }^{50}$ However, due to the considerably different laws regarding early release among the enforcement states, an informal rule has developed according to which prisoners sentenced by the Tribunals become eligible for review after two-thirds of their sentence have been served. ${ }^{51}$ The ICc has enshrined the two-thirds rule, which

45 For a discussion of the extraordinary nature of international crimes see Alexander Alvarez, 'Adjusting to genocide: The techniques of neutralization and the holocaust', 21(2) Social Science History (1997) 139-178; Drumbl, supra note 2; Stefan Harrendorf, 'How can criminology contribute to an explanation of international crimes?', 12(2) Journal of International Criminal Justice (2014) 231-252; Herbert Jäger, Makrokriminalität: Studien zur Kriminalität kollektiver Gewalt (Suhrkamp, Frankfurt/Main, 1989); Mark A. Mattaini, 'Understanding and reducing collective violence', 12 Behaviour and Social Science (2003) 90108; Frank Neubacher, 'How can it happen that horrendous state crimes are perpetrated? An overview of criminological theories', 4Journal of International Criminal Justice (2006) 787-799; Ervin Staub, 'The origins and prevention of genocide, mass killing, and other collective violence', 5(4) Peace and Conflict: Journal of Peace Psychology (1999) 303-336; James E. Waller, 'The Ordinariness of Extraordinary Evil: The Making of Perpetrators of Collective Violence', in Allette Smeulers (ed.), Collective Violence and International Criminal Justice (Intersentia, Antwerp, 2010), pp. 19-37.

46 Beresford, supra note 31; Alette Smeulers and Barbora Holá, 'ICTY and the culpability of different types of perpetrators of international crimes', in Smeulers (ed.), ibid., pp. $175^{-205}$.

$47 \quad$ Holá and van Wijk, supra note 42.

48 Kelder, Holá and van Wijk, supra note 11.

49 As stipulated in IстY Statute, Art. 28.

5o Kelder, Holá and van Wijk, supra note 11.

51 Choi, supra note 10; Holá, Smeulers and Bijleveld, supra note 13. The President of the MICT has also decided on the two-thirds rule for any subsequent early release eligibility, see 
has developed out of the early release practice of the ICTY, in the Rome Statute as a review process that is automatically triggered when the time-bound threshold has been reached. ${ }^{52}$ At the ICC, three judges of the Appeals Chamber preside over decisions on early release. In case of a denial of early release, the sentence may be reviewed again by the Appeals Chamber 'every three years, unless it establishes a shorter interval. ${ }^{53}$ It should be noted that early release at the Tribunals and the ICC are entirely unconditional. Parole, which is a rather frequent feature in domestic jurisdictions, commonly hinges on a requirement of demonstrable rehabilitation and usually coupled with a monitoring mechanism, is non-existent in international criminal law doctrine. ${ }^{54}$ Recently however, in the early release decision of Ćorić, the President of the MICT has deliberated whether conditions should be imposed on the release of international convicts ${ }^{55}$ and he imposed a number of conditions on Ćorić, such as prohibition of contact with victims or witnesses who testified, prohibition of use of weapons, and honourable conduct in the community, stating that violation of these conditions engenders the revocation of conditional release. ${ }^{56}$ No mechanism is in place at the Tribunals nor at the ICC to supervise or even monitor prisoners once they have been released ${ }^{57}$ and "[a]fter release, international prisoners are literally "off the radar". 58

A sentence of life imprisonment presents a particular challenge to the practice of early release, and, by extension, to the notion of rehabilitation. By definition, a life sentence precludes any expectation of the convicted person returning to the community, and therefore intuitively renders rehabilitation irrelevant. Neither the Statute nor the RPE of the Tribunals discuss this dilemma, and the Presidents of the ICTR and the ICTY have not been presented with it; however, in Galic the President of the MICT asserted that, 'the possibility of early release applies to all convicted persons, including those sentenced to life

MICT, Prosecutor v. Bisengimana, Case No. MICT-12-07, The President of the Mechanism, Decision of the President on Early Release of Paul Bisengimana and on Motion to File a Public Redacted Application, 11 December 2012.

$5^{2}$ ICC Statute, Art. 110(3).

53 ICC RPE, Rule 224(3).

54 Choi, supra note 10. It should be noted that conditional release does exist within the jurisdiction of the Special Court for Sierra Leone (see Practice Direction on the Conditional Early Release of Persons Convicted by the Special Court for Sierra Leone).

MICT, Prosecutor v. Ćorić, Case No. MICT-17-112-ES.4, The President of the Mechanism, Further Redacted Public Redacted Version of the Decision of the President on the Early Release of Valentin Ćorić and Related Motions, 16 January 2019, para. 73.

56 Ibid., para. 78.

57 Choi, supra note 10; Kelder, Holá and van Wijk, supra note 11.

58 Holá and van Wijk, supra note 42. 
imprisonment'. ${ }^{59}$ Furthermore, referencing international standards, the President noted that the aim of imprisonment to advance rehabilitative goals 'would be rendered meaningless if a prisoner is not afforded the possibility of having his or her sentence reviewed. ${ }^{60}$ Regarding the challenge of calculating an appropriate point of eligibility for early release of those sentenced to life imprisonment, the President of the MICT considered it appropriate that persons sentenced by the Tribunals be eligible for early release 'upon having served more than two-thirds of the highest fixed-term sentence imposed by the ICTR, the ICTY, or the Mechanism'61 though this does not necessarily forestall the possibility of review or release before reaching this threshold. ${ }^{62}$ In contrast, the ICC has averted such a quandary and Article 110(3) of the Rome Statute holds that an automatic review process is triggered after 25 years of a life sentence have been served - and not any time before this point. ${ }^{63}$ By creating a normative standard for the eligibility for early release in cases of life sentences, both the ICTY and the ICC thus allow rehabilitation to remain, at least in theory, a relevant aim in sentencing.

\section{The Concept of Rehabilitation at the ICTY}

3.1 The Concept of Rehabilitation within the Judgments of the ICTY

Not all judgments rendered by the ICTY Trial Chamber reflect on the aims of sentencing, and even fewer judgments rendered by the ICTY Appeals Chamber do so. Furthermore, many judgments that do briefly reflect on the aims of sentencing in general make no reference to the specific aim of rehabilitation at all. Indeed, when rehabilitation is considered as a sentencing aim - albeit usually very briefly - it features almost as an afterthought. While the general relevance

59 MICt, Prosecutor v. Galić, Case No. MICt-14-83-ES, The President of the Mechanism, Reasons for the President's Decision to Deny the Early Release of Stanislav Galić, 23 June 2015, para. 21.

6o Ibid., para. 22. The President also referred to the case Ec HR Vinter and Others v. The United Kingdom, nos. 66069/o9, 130/10 and 3896/10, Judgment, 9 July 2013, paras. 110-119, which affirmed that all prisoners, including those sentenced for life, should be eligible for a sentence review, in light of 'the rehabilitative principle and respect for human dignity' and the prohibition of inhuman and degrading treatment under the European Convention on Human Rights.

61 Galić, Reasons for the President's Decision to Deny the Early Release of Stanislav Galić, supra note 59 , para. 36 .

$62 \quad$ Ibid., para. 39.

63 The threshold of 25 years at the ICc equals five-sixth of the highest sentence it could impose besides life imprisonment, which is notably higher than at the Tribunals. 
of rehabilitation in this context is acknowledged, it is frequently emphasised that retribution and deterrence are the preeminent sentencing aims; rehabilitation merits considerably less consideration and 'should not be given undue weight'.64 The limited discussion of rehabilitation as a sentencing aim is often also accompanied by an expression of doubt concerning the effectiveness of rehabilitation; ' $[\mathrm{e}] \mathrm{xperience}$ the world over has shown that it is a controversial proposition that imprisonment alone - which is the only penalty that a Trial Chamber may impose - can have a rehabilitative effect on a convicted person'. ${ }^{65}$ Indeed, the key reason given for assigning rehabilitation this inferior status as a sentencing aim is that the gravity of the crimes that the Tribunal adjudicates on, is very high, and therefore rehabilitation should not be a central aim, compared to deterrence and retribution. ${ }^{66}$ However, the reasoning for this argument is not entirely clear. It could be postulated that due to the high gravity of the crimes in question, there is an underlying belief that the perpetrators of such egregious violations of humanitarian law do not embody any potential to become rehabilitated - that somehow the goal of rehabilitation is reserved for perpetrators of 'lesser' offences and is too ambitious in the cases that come before the Tribunal.

Rehabilitation as a sentencing aim also features in the consideration of mitigating circumstances. ${ }^{67}$ As mentioned above, there are no sentencing guidelines at the ICTY, and the sentence should be individualised taking into account the character of the perpetrator, which includes scrutinising such factors in order to assess the accused's 'potential for rehabilitation'.68 As the Trial

64 E.g., ICTY, Prosecutor v. Stakić, Case No. IT-97024-A, Appeals Chamber, Judgment, 22 March 2006, para. 402. See also ICTY, Prosecutor v. Gotovina et al., Case No. IT-o6-9o-T, Trial Chamber, Judgment Volume II of II, 15 April 2011, para. 1598; ICTY, Prosecutor v. Haradinaj et al., Case No. IT-04-84-T, Trial Chamber, Judgment, 3 April 2008, para. 488; ICTY, Prosecutor v. Krajišnik, Case No. IT-oo-39-T, Trial Chamber, Judgment, 27 September 2006, para. 1138; ICTY, Prosecutor v. Krajišnik, Case No. IT-oo-3o-A, Appeals Chamber, Judgment, 18 March 2009, para. 806; ICTY, Prosecutor v. Popović et al., Case No. IT-05-88-T, Trial Chamber, Judgment, 10 June 2010, para. 2130; para. 1211.

65 ICTY, Prosecutor v. Kunarac et al., Case No. IT-96-23-T \& IT-96-23/1-T, Trial Chamber, Judgment, 22 February 2001, para. 844.

66 ICTY, Prosecutor v. Tolimir, Case No. IT-05-88/2-T, Trial Chamber, Judgment, 12 December 2012, para. 1211.

67 In ICTY, Prosecutor v. Obrenović, Case No. IT-02-6o/2-S, Trial Chamber, Sentencing Judgment, 10 December 2003, para. 143, the Trial Chamber stated that, 'where an accused has demonstrated that he has already taken affirmative steps on the path toward rehabilitation, and that the process of rehabilitation is likely to continue in the future that this should be recognised in mitigation of sentence'.

68 ICTY, Prosecutor v. Blaškić, Case No. IT-95-14-T, Trial Chamber, Trial Judgment, 3 March 200o, para. 765. See also ICTY, Prosecutor v. Galić, Case No. IT-98-29-T, Trial Chamber, 
Chamber in Blaškić stated, "The character traits are not so much examined in order to understand the reasons for the crime but more to assess the possibility of rehabilitating the accused'. ${ }^{69}$ In this pursuit, a variety of individual characteristics of the perpetrator and circumstances of the crimes are considered, ${ }^{70}$ though the perpetrator's good character specifically is often cited as relevant in this context and maintaining relations with one's family supposedly indicates 'good rehabilitative prospects'. ${ }^{71}$ Rehabilitation is almost exclusively conceptualised as the extent to which there is a prospect for reintegration. ${ }^{72}$ Individual circumstances are then assessed in this view, as indicative of the perpetrator's potential to be reintegrated into society.

As in many domestic jurisdictions, remorse is also considered as a mitigating factor in sentencing at the ICTY and viewed in light of an accused's rehabilitative potential; it is supposed to signify a 'personal transformation.' ${ }^{73}$ Indeed, guilty pleas, remorse and rehabilitation are occasionally conceptually linked in the judgments; for instance, the Trial Chamber in Plavsić stated that, 'by her guilty plea, Mrs Plavšić had already demonstrated remorse, ${ }^{74}$ and in Bralo it was stated that the accused's 'voluntary surrender and guilty plea before the Tribunal are inextricably linked to his remorse and steps towards

Judgment and Opinion, 5 December 2003, para. 759; ICTY, Prosecutor v. Kvočka et al., Case No. IT-98-30/1-T, Trial Chamber, Judgment, 2 November 2001, para. 704.

69 Blaškić, Trial Judgment, supra note 68, para. 780.

70 'Mitigating factors include co-operation with the Prosecution; the admission of guilty or a guilty plea; the expression of remorse; sympathy, compassion, or sorrow for the victims of the crimes; voluntary surrender; good character with no prior criminal convictions; comportment while in detention; personal and family circumstances; the character of the convicted person subsequent to the conflict; duress; indirect participation; diminished mental responsibility; age; and assistance to detainees or victims' - see ICTY, Prosecutor v. Milutinović et al., Case No. IT-05-87-T, Trial Chamber, Judgment, 26 February 2009, para. 1152. See also, Obrenović, Sentencing Judgment, supra note 67, para. 144; ICTY, Prosecutor v. Hadžihasanović \& Kubura, Case No. IT-01-47-T, Trial Chamber, Judgment, 15 March 2006, para. 2080; Blaškić, Trial Judgment, supra note 68, para. 781.

71 ICTY, Prosecutor v. Kordić \& Čerkez, Case No. IT-95-14/2-A, Appeals Chamber, Judgment, 17 December 2004, para. 1091.

72 See ICTY, Prosecutor v. Delalić et al., Case No. IT-96-21-T, Trial Chamber, Judgment, 16 November 1998, para. 1233; ICTY, Prosecutor v. Češić, Case No. IT-95-10/1-S, Trial Chamber, Sentencing Judgment, 11 March 2004, para. 27; Kordić \& Čerkez, Judgment, supra note 71, para. 1079.

73 ICTY, Prosecutor v. Bralo, Case No. IT-95-17-S, Trial Chamber, Sentencing Judgment, 7 December 2005, para. 69.

74 ICTY, Prosecutor v. Plavšić, Case No. IT-00-39\&40/1-S, Trial Chamber, Sentencing Judgment, 27 February 2003, para 73 . 
rehabilitation. ${ }^{75}$ It should be noted that according to research, acceptance of guilt or responsibility and remorse must not necessarily co-occur and there is also a wealth of evidence refuting an association between displays of remorse and lowered recidivism. ${ }^{76}$ Based on the foregoing, it becomes apparent that where it is mentioned, rehabilitation is invoked in light of individual circumstances; and where remorse or guilty pleas are considered, it is done so, by large, in light of how these factors affect the accused's personal rehabilitation. Only in some instances does the Trial Chamber reflect upon the potential of a guilty plea, coupled with an expression of remorse, to contribute towards reconciliation of the affected communities. ${ }^{77}$

Within the ICTY judgments, it is never thoroughly explained how the convicted persons are supposed to achieve rehabilitation. Few judgments make reference to a supposed mechanism of the rehabilitation process; these mention that the rehabilitative purpose of punishment is partly fulfilled by the accused's demonstrated reflection on the crimes committed and the harm that had been caused to victims. For instance, it is contended that facing the victims' testimonies and reflecting on the crimes 'can inspire tolerance and

75 Bralo, Sentencing Judgment, supra note 73, para. 6o; see also, Češić, Sentencing Judgment, supra note 72, para. 28; ICTY, Prosecutor v.Jokić, Case No. IT-01-42/1-S, Trial Chamber, Sentencing Judgment, 18 March 2004, para. 36; ICTY, Prosecutor v. Babić, Case No. IT-03/72-S, Trial Chamber, Sentencing Judgment, 29 June 2004, para. 46; ICTY, Prosecutor v. Mrda, Case No. IT-02-59-S, Trial Chamber, Sentencing Judgment, 31 March 2004, paras. 18-19.

76 E.g., see Holá, van Wijk, Constantini and Korhonnen, supra note 9; June Price Tangney, Jeff Stuewig and Logaina Hafez, 'Shame, guilt and remorse: Implications for offender populations', 22(5) The Journal of Forensic Psychiatry \& Psychology (2011) 706-723; Michael J. Proeve, David I. Smith and Diane M. Niblo, 'Mitigation without definition: Remorse in the criminal justice system', 32(1) New Zealand Journal of Criminology (1999) 16-26; Michael Prove and Steven Tudor, Remorse: Psychological and Jurisprudential Perspectives (Ashgate, Burlington, VT, 2010); Susan A. Bandes, 'Remorse and criminal justice', 8(1) Emotion Review (2016) 14-19.

77 ICTY, Prosecutor v. Momir Nikolić, Case No. IT-02-6o/1-S, Trial Chamber, Sentencing Judgment, 2 December 2003, para 72; Češić, Sentencing Judgment, supra note 72, para. 58; Jokić, Sentencing Judgment, supra note 75, para. 77; ICTY, Prosecutor v. Deronjić, Case No. IT-0261-S, Trial Chamber, Sentencing Judgment, 30 March 2004, para. 236; Bralo, Sentencing Judgment, supra note 73, para. 71. Indeed, genuine remorse is often cited as a crucial element in restorative justice processes, as it is purported to aid in the healing of victims and to facilitate reconciliation between victims and offenders; see Tony Ward, Kathryn J. Fox and Melissa Garber, 'Restorative justice, offender rehabilitation and desistance', 2(1) Restorative Justice: An International Journal (2014) 24-42. Nevertheless, the difficulty of assessing sincerity of remorse in a courtroom is woefully depicted in the case of Biljana Plavšić's false remorse; see Plavšić, Sentencing Judgment, supra note 74; Jelena Subotić, 'The cruelty of false remorse: Biljana Plavšić', 36 Southeastern Europe (2012) 39-59; Kate Rossmanith, 'Courtroom contrition: How do judges know?', 22(2) Griffith Law Review (2013) 366-384. 
understanding of the 'other', thereby reducing the risk of recidivism'; or that deprivation of liberty may inspire contemplation of one's offences and responsibility for the harm caused, which may aid in the reintegration process. ${ }^{78}$

The ICTY judgments' deliberations on the rehabilitative purpose of punishment exhibit a striking inconsistency regarding the possibility of reoffending. Sometimes, the judgments state that the rehabilitative aim of punishment serves to decrease the likelihood that the perpetrator will reoffend in the future, ${ }^{79}$ however, several judgments also contain doubt concerning the potential for realising the ambitious goal of rehabilitation. ${ }^{80}$ In other places, the Trial Chamber states that individual deterrence and its aim to decrease recidivism should not be given too much weight as a sentencing aim, ${ }^{81}$ precisely because it is acknowledged that there is exceptionally low risk of the perpetrators ever committing such crimes again regardless, due to the drastically changed sociopolitical climate in the former Yugoslavia. ${ }^{82}$ In this regard, there exists little coherence in terms of the conceptualisation of rehabilitation as a sentencing aim and its relationship with recidivism. On the one hand, rehabilitation is conceptualised as a necessary mechanism that aids in achieving the goal of perpetrators never offending again. On the other hand, rehabilitation is either treated as a superfluous consideration given its supposed unattainability or rendered redundant given the extremely unlikely possibility of recidivism in the specific circumstances of these perpetrators of international crimes.

\subsection{The Concept of Rehabilitation within the Early Release Decisions of the ICTY}

Despite the cursorily references to rehabilitation in the judgments of the ICTY, the absence of a concrete definition of what it entails and how it should manifest, rehabilitation comes into focus within the deliberations contained in the early release decisions. Though this is perhaps not surprising, since rehabilitation is formally required to be a consideration therein, ${ }^{83}$ it still appears paradoxical, since the judgments emphasise rehabilitation to carry little weight as

$78 M r đ a$, Sentencing Judgment, supra note 75, para. 18. See also, Babić, Sentencing Judgment, supra note 75, para. 46; Jokić, Sentencing Judgment, supra note 75, para. 35.

79 ICTY, Prosecutor v. Kupreškić et al., Case No. IT-95-16-T, Trial Chamber, Judgment, 14 January 2000, para. 849 .

$80 \quad$ Kunarac, Judgment, supra note 65 , para. 844 .

81 See Jokić, Sentencing Judgment, supra note 75, para. 34; Gotovina et al., Judgment Volume II of II, supra note 64, para. 2696; Mrda, Sentencing Judgment, supra note 75, para. 17.

82 Češić, Sentencing Judgment, supra note 72, para. 26; Gotovina et al., Judgment Volume II of II, supra note 64, para. 2696; Jokić, Sentencing Judgment, supra note 75, para. 34; Kunarac., Judgment, supra note 65 , para. 843 .

ICTY RPE, Rule 125. 
a sentencing aim. Among the factors to be taken into account in considering the eligibility for early release, having served two-thirds of one's sentence seems to be the most significant factor bearing on the decision. ${ }^{84}$ Indeed, the most commonly cited reasons for denying early release, often in spite of apparently demonstrably good behaviour in detention, is the high gravity of the crimes committed ${ }^{85}$ and the observation that at the time of application for early release the customary threshold of having served two-thirds of the sentence had not yet been met. ${ }^{86}$ Often, these reasons prevail in denying early release, in spite of signs indicating rehabilitation. Rarely is a lack of rehabilitation the decisive factor in denying early release, even when two-thirds of the sentence have been served by the convicted person. ${ }^{87}$ On the other hand, even

84 See Holá and van Wijk, supra note 42.

85 See Galić, Reasons for the President's Decision to Deny the Early Release of Stanislav Galić, supra note 59 para, 17; мICT, Prosecutor v. Galić, 2017, Case No. MICT-14-83-ES, The President of the Mechanism, Decision of the President on the Early Release of Stanislav Galić, 18 January 2017, para. 18; ICTY, Prosecutor v. Kordić, Case No. IT-95-14/2-ES, The President of the International Tribunal, Decision of President on Application for Pardon or Commutation of Sentence, 13 May 2010, para. 23; ICTY, Prosecutor v. Mrkšić, Case No. IT95-13/1-ES.2, The President of the International Tribunal, Decision of the President on the Early Release of Mile Mrkšić, 13 December 2013, para. 29; МICT, Prosecutor v. Miletić, Case No. MICT-15-85-ES.5, The President of the Mechanism, Decision of the President on the Early Release of Radivoje Miletić, 27 July 2017, para. 35; ICTY, Prosecutor v. Rajić, Case No. IT-95-12-ES, The President of the International Tribunal, Decision of President on Early Release of Ivica Rajić, 31 January 2011, para. 24.

86 See mict, Prosecutor v. Jelisić, Case No. MICT-14-63-ES, The President of the Mechanism, Public Redacted Version of 22 May 2017 Decision of the President on Recognition of Commutation of Sentence, Remission of Sentence, and Early Release of Goran Jelisić, $11 \mathrm{Au}-$ gust 2017; MICT, Prosecutorv. Krstić, Case No. MICT-13-46-ES.1, The President of the Mechanism, Decision of the President on the Early Release of Radislav Krstić, 13 December 2016, para. 39; Mrkšić, Decision of the President on the Early Release of Mile Mrkšić, supra note 85, para. 29; MICT, Prosecutor v. Drago Nikolić, Case No. MICT-15-85-ES.4, The President of the Mechanism, Public Redacted Version of the 20 July 2015 Decision of the President on the Application for Early Release or Other Relief of Drago Nikolić, 13 October 2015 .

87 For examples of early release being granted despite the convicted person's denial of having committed the crimes they were convicted for and failure to show remorse see: MICT, Prosecutor v. Kunarac, Case No. MICT-15-88-ES.1, The President of the Mechanism, Decision of the President on the Early Release of Dragoljub Kunarac, 2 February 2017, para. 68; ICTY, Prosecutor v. Radić, Case No. IT-98-30/1-ES, The President of the International Tribunal, Decision of the President on Commutation of Sentence, 22 June 2007, para. 15; ICTY, Prosecutor v. Radić, Case No. IT-98-30/1-ES, The President of the International Tribunal, Decision of President on Application for Pardon or Commutation of Sentence of Mlađo Radić, 23 April 2010, para. 21; ICTY, Prosecutor v. Radić, Case No. IT-98-30/1-ES, The President of the International Tribunal, Public Redacted Version of 13 February 2012 Decision of the President on Early Release of Mlađo Radić, 9 January 2013, para. 26; ICTY, 
when the convicted person has repeatedly denied any responsibility or participation in the crimes, the two-thirds rule has prevailed in determining whether and when early release should be granted. ${ }^{88}$

In contrast, a large number of cases exist where seemingly trivial aspects of the convicted person's life in detention are treated as indicative of a satisfactory level of rehabilitation. Good behaviour in detention and an absence of disciplinary infractions are often considered as factors weighing in favour of early release; ${ }^{89}$ both are often taken to signify that good reintegration is to be expected. ${ }^{90}$ Many early release decisions citing reports from prison authorities state that international prisoners are exemplary prisoners. This is unsurprising, given the special aetiology of international crimes ${ }^{91}$ and findings that the vast majority of those before the Tribunals were law-abiding, ordinary citizens before the outbreak of hostilities. ${ }^{92}$ Often the good behaviour is expressed in relation to following rules, respecting the authority of the prison staff ${ }^{93}$ - behaviour

Prosecutor v. Bala, Case No. IT-03-66-ES, The President of the International Tribunal, Decision on Application of Haradin Bala for Sentence Remission, 15 October 2010, para. 19.

88 ICTY, Prosecutor v. Krajišnik, Case No. IT-oo-39-ES, The President of the International Tribunal, Decision of President on Early Release on Momčilo Krajišnik, 2 July 2013, para. 24.

89 See ICTY, Prosecutor v. Tarčulovski, Case No. IT-04-82-ES, The President of the International Tribunal, Decision of President on Early Release of Johan Tarčulovski, 8 April 2013, paras. 21-23; ICTY, Prosecutor v. Jokić, Case No. IT-01-42/1-ES, The President of the International Tribunal, Decision of the President on Request for Early Release, 1 September 2008, para. 8; MICT, Prosecutor v. Šainović, Case No. MICT-14-67-ES.1, The President of the Mechanism, Public Redacted Version of the 10 July 2015 Decision of the President on the Early Release of Nikola Šainovic, 17 August 2015, para 16; ICTY, Prosecutor v. Tadić, Case No. IT95-9, The President of the International Tribunal, Decision of the President on the Application for Pardon or Commutation of Sentence of Miroslav Tadić, 24 June 2004, para. 6; ICTY Prosecutor v. Strugar, Case No. IT-01-42-ES, The President of the International Tribunal, Decision of the President on the Application for Pardon or Commutation of Sentence of Pavle Strugar, 16 January 2009, para. 10.

9o Galić, Reasons for the President's Decision to Deny the Early Release of Stanislav Galić, supra note 59, para. 44 .

91 See supra note 45.

92 Beresford, supra note 31; Alette Smeulers, 'Perpetrators of international crimes: Towards a typology', in Alette Smeulers and Roelof H. Haveman (eds.), Supranational Criminology Towards a Criminology of International Crimes (Intersentia, Antwerp, 2008) pp. 1333-265.

93 See MICt, Prosecutor v. Pušić, Case No. MICT-17-112-ES.1, The President of the Mechanism, Public Redacted Version of the 20 April 2018 Decision of the President on the Early Release of Berislav Pušić, 24 April 2018, para. 38; ICTY, Prosecutor v. Ojdanić, Case No. IT-0587-ES.1, The President of the International Tribunal, Public Redacted Version of the 10 July 2013 Decision of the President on Early Release of Dragoljub Ojdanić, 29 August 2013, para. 18; MICT, Prosecutor v. Lazarević, Case No. MICT-14-67-ES.3, The President of the Mechanism, Public Redacted Version of the 7 September 2015 Decision of the President on the Early Release of Vladimir Lazarević, 3 December 2015, para. 18; MICT, Prosecutor v. 
that could perhaps be seen as problematic in people who were convicted on the basis of following orders, such as lower-ranking military staff. ${ }^{94}$

In general, the President of the ICTY (and the President of the MICT) appears to embrace any trivial indicators that could be generously interpreted as signs of rehabilitation to justify the perfunctory process of deliberating whether to grant early release after two-thirds of a sentence have been served. Often, the factors that are relevant for the consideration of mitigating circumstances in the trial judgments are also taken into account here in the context of early release decisions. ${ }^{95}$ Some apparent testimonies of rehabilitation sound almost banal in the face of the sheer scope and gravity of the crimes these people have been convicted of. For example, employment in prison facilities, ${ }^{96}$ participation in social activities offered in prison ${ }^{97}$ and sports ${ }^{98}$ and efforts to learn the language of the country where they are imprisoned ${ }^{99}$ are seen as 'a sincere

Pandurević, Case No. MICT-15-85-ES.1, The President of the Mechanism, Public Redacted Version of the 9 April 2015 Decision of the President on the Early Release of Vinko Pandurević, 10 April 2015, para. 23.

94 For a discussion on the different types of perpetrators on trial at the ICTY, see Smeulers and Holá, supra note 46.

95 ICTY, Prosecutor v. Boškoski \& Tarčulovski, Case No. IT-04-82-T, Trial Chamber, Trial Judgment, 10 July 2008, para. 597.

96 See Jokić, Decision of the President on Request for Early Release, supra note 89, para. 8; ICTY, Prosecutor v. Obrenović, Case No. IT-02-6o/1-ES, The President of the International Tribunal, Decision of President on Early Release of Dragan Obrenović, 21 September 2011, para. 21; ICTY, Prosecutor v. Sikirica, Case No. IT-95-8-ES, The President of the International Tribunal, Decision of President on Early Release of Duško Sikirica, 21 June 2010, para. 18; ICTY, Prosecutor v. Simić, Case No. IT-95-9-ES, The President of the International Tribunal, Decision of President on Early Release of Blagoje Simić, 15 February 2011, para. 22.

97 See Ojdanić, Public Redacted Version of the 10 July 2013 Decision of the President on Early Release of Dragoljub Ojdanić, supra note 93, para. 18; мICт, Prosecutor v. Zelenović, Case No. Mict-15-89-ES, The President of the Mechanism, Public Redacted Version of the 28 August 2015 Decision of the President on the Early Release of Dragon Zelenović, 15 September 2015, para. 16 .

98 See Galić, Reasons for the President's Decision to Deny the Early Release of Stanislav Galić, supra note 59, para. 41; ICTY, Prosecutor v. Landžo, Case No. IT-96-21-ES, The President of the International Tribunal, Order Issuing a Public Redacted Version of the President on Commutation of Sentence, 15 July 2008, para. 6.

99 See ICty, Prosecutor v. Erdemović, Case No. IT-96-22-ES, The President of the International Tribunal, Order Issuing a Public Redacted Version of Decision of the President on Early Release, 15 July 2008; Galić, Reasons for the President's Decision to Deny the Early Release of Stanislav Galić, supra note 59, para. 42; ICTY, Prosecutor v. Šantić, Case No. IT-95-16-ES, The President of the International Tribunal, Decision of the President on the Application for Pardon or Commutation of Sentence of Vladimir Šantić, 16 February 2009, para. 12; ICTY, Rajić, Decision of President on Early Release of Ivica Rajić, supra note 81, para. 18; 
attempt at social reintegration'100 and are frequently cited as factors demonstrating rehabilitation. This could appear almost absurd in light of both the extreme gravity of the crimes; and - paradoxically - also the observation that the majority of perpetrators have likely lived as non-deviant ordinary people before committing the atrocities. In addition, the convicts' plans for life after release are also seen as indicators that they will be successful at reintegrating into society. ${ }^{101}$ As such, rehabilitation here is also phrased in the language of reintegration - in the sense that rehabilitation renders the convict 'capable of reintegrating into society'.102 Occasionally, the President will also refer to reports by prison authorities that attest to the low risk of recidivism presented by the convicts in case of their release to society. It is common that they attest to a low likelihood of committing any further offences. ${ }^{103}$ This is entirely unsurprising, given the largely non-deviant character of the convicts before the war ${ }^{104}$ and also given the fact that the war has since ended. ${ }^{105}$

Furthermore, demonstration of remorse is sometimes mentioned in the early release decisions as a necessary factor for the rehabilitation of the convicted person. ${ }^{106}$ Various variations of supposed demonstrated remorse

MICT, Prosecutor v. Stakić, Case No. MICT-13-6o-ES, Decision of the President on Sentence Remission of Milomir Stakić, 17 March 2014, para. 23.

100 ICTY, Prosecutor v. Banović, Case No. IT-02-65/1-ES, The President of the International Tribunal, Decision of the President on Commutation of Sentence, 3 September 2008, para. 13.

101 See Jokić, Decision of the President on Request for Early Release, supra note 89, para. 8; Kordić, Decision of President on Application for Pardon or Commutation of Sentence of Dario Kordić, supra note 85, para. 19; ICTY, Prosecutorv. Vuković, Case No. IT-96-23 \& 23/1ES, The President of the International Tribunal, Decision of the President on Commutation of Sentence, 11 March 2008, para. 6; ICTY, Prosecutor v. Kovač, Case No. IT-96-23 \& 23/1-ES, The President of the International Tribunal, Public and Redacted Version of the 27 March 2013 Decision of President on Early Release of Radomir Kovać, 3 July 2013, para. 24.

102 Pandurević, Public Redacted Version of the 9 April 2015 Decision of the President on the Early release of Vinko Pandurević, supra note 93, para. 25; Miletić, Public Redacted Version of the 26 July 2017 Decision of the President on the Early Release of Radivoje Miletić, supra note 85 , para. 30 .

103 Galić, Reasons for the President's Decision to Deny the Early Release of Stanislav Galić, supra note 59, para. 42; Galić, Decision of the President on the Early Release of Stanislav Galić, supra note 85, para. 26; мICT, Prosecutor v. Kordić, Case No. MICT-14-68-ES, The President of the Mechanism, Public Redacted Version of the 21 May 2014 Decision of the President on the Early Release of Dario Kordić, 6 June 2014, para. 20.

104 Beresford, supra note 31; Smeulers and Holá, supra note 46.

105 See Zelenović, Decision of the President on the Early Release of Dragan Zelenović, supra note 97, para 19 .

106 E.g., see ICTY, Prosecutor v. Bala, Case No. IT-03-66-ES, The President of the Tribunal, Public Redacted Version of the 28 June 2012 Decision of the President on Early Release of Haradin Bala, 9 January 2013, para. 25. 
include feeling 'bad' about the deeds, accepting guilt, showing remorse, expressing this to victims, often in connection to a guilty plea. ${ }^{107}$ This rather nebulous notion of what remorse should look like also evokes the conflated distinction between acceptance of responsibility and expressions of remorse that is evident in the judgments. ${ }^{108}$ In all instances where remorse is said to be expressed by the convicted person, the President counts this as a sign of rehabilitation (whether it be sufficient for early release or not), mirroring the Trial Chambers' language in the judgments, it is viewed as an indication that the convicted person is 'capable of reintegrating into society'. ${ }^{109}$ However, remorse is clearly not an essential requirement for rehabilitation, as several examples of early release decisions show that the convicted person was considered to display some rehabilitation - though they were not granted early release in these instances - despite a blatant denial of responsibility and a demonstrated lack of remorse for the crimes committed. In some early release decisions, it is argued that a failure to show sincere remorse does not necessarily reveal an absence of rehabilitation; in a telling passage in Stakić's first early release decision the President states,

I note with concern Mr. Stakić's refusal to take responsibility for the crimes for which he was convicted. However, I also note that Mr. Stakić has shown good behaviour in detention and his willingness to improve his language skills so as to integrate into the prison environment. Under these circumstances, I consider that Mr. Stakić has demonstrated some albeit very limited - signs of rehabilitation. ${ }^{110}$

107 See Banović, Decision of the President on Commutation of Sentence, supra note 100, para. 13; Kovač, Decision of President on Early Release of Radomir Kovać, supra note 101, para. 22; Šantić, Decision of the President on the Application for Pardon or Commutation of Sentence of Vladimir Šantić, supra note 99, para. 11; Landžo, Order of the President on Commutation of Sentence, supra note 98, para. 7; ICTY, Prosecutor v. Naletilić, Case No. IT-98-34-ES, The President of the Mechanism, Public Redacted Version of the 29 November 2012 Decision of the President on Early Release of Mladen Naletilić, 26 March 2013, para. 26; ICTY, Prosecutor v. Dragan Nikolić, Case No. IT-92-2-ES, The President of the International Tribunal, Decision of President on Early Release of Dragan Nikolić, 16 January 2014, para. 28; Ojdanić, Decision of the President on Early Release of Dragoljub Ojdanić, supra note 93, para. 19 .

108 As has been emphasised by some scholars, it is entirely possible to embody one sentiment without the other; see Holá, van Wijk, Constantini and Korhonnen, supra note 9.

109 MICT, Prosecutor v. Češić, Case No. MICT-14-66-ES, The President of the Mechanism, Public Redacted Version of the 30 April 2014 Decision of the President on the Early Release of Ranko Česič, 28 May 2014, paras. 20-21.

110 ICTY, Prosecutor v. Stakić, Case No. IT-97-24-ES, The President of the International Tribunal, Decision of President on Early Release of Milomir Stakić, 15 July 2011, para. 34. Milomir Stakić was not granted early release based on this application. 
This quote highlights the relative weight certain factors are given in the deliberations on whether sufficient rehabilitation has been demonstrated. Some convicted persons have even been granted early release even in the absence of remorse and the President has been satisfied with other factors as sufficient indicators for achieving an acceptable level of rehabilitation to outweigh this. ${ }^{111}$

The Concept of Rehabilitation at the ICC as Compared to the ICTY

\section{1}

\section{The Concept of Rehabilitation within the Sentencing Decisions of the Icc}

As with the Tribunals, the main sentencing objectives at the ICC are deterrence and retribution, ${ }^{112}$ though retribution here is conceptualised more along the lines of 'expression of society's condemnation of the criminal act and of the person who committed it, which is also a way of acknowledging the harm and suffering caused to the victims'.13 However, in contrast to the ICTY, reconciliation and justice for victims are also considered prominent purposes of sentencing. Indeed, the Rome Statute does provide for comparatively more extensive role for victims and their interests than the Tribunals' statutes, arguably to further reconciliatory efforts. ${ }^{114}$ This emphasis on reconciliation is particularly notable, along with a near absence of rehabilitation - in the sense of rehabilitation of the individual perpetrator - in the positive law as well as the case-law of the ICc. As a caveat, only five individuals have been sentenced by the ICC thus far, hence the ability to make generalisations about the court's conceptualisation of rehabilitation in case-law is limited. Nonetheless, it is striking that 'rehabilitation' is mentioned in the context of the individual circumstances of the perpetrator in only one sentencing decision; in Katanga,

111 See Kovač, Decision of President on Early Release of Radomir Kovać, supra note 101, para. 28; Tarčulovski, Decision of President on Early Release of Johan Tarčulovski, supra note 89, para. 23; ICTY, Prosecutor v. Šljivančanin, Case No. IT-95-13/1-ES, The President of the International Tribunal, Decision of President on Early Release of Veselin Šljivančanin, 5 July 2011, para. 26.

112 ICC, Prosecutor v. Al Mahdi, Case No. ICC-01/12-01/15, Trial Chamber, Judgment and Sentence, 27 September 2016, para. 66; ICC, Prosecutor v. Bemba, Case No. ICC-01/05-01/08, Trial Chamber, Decision on Sentence pursuant to Article 76 of the Statute, 21 June 2016, para. 10.

113 ICC, Prosecutor v. Katanga, Case No. ICC-01/04-01/07, Trial Chamber, Decision on Sentence pursuant to Article 76 of the Statute, 10 July 2012, para. 38 .

114 See Elisabeth Baumgartner, 'Aspects of victim participation in the proceedings of the International Criminal Court', 9o(870) International Review of the Red Cross (2008) 409-440. See also, ICC Statute, Art. 68(3). 
the perpetrator's young age and his family circumstances were considered by the Trial Chamber as mitigating factors for they are likely to make rehabilitation and reintegration easier.'115 In two further sentencing decisions the word 'rehabilitation' appears, however only as part of a general allusion to the sentencing aims at large ${ }^{116}$ cautioning in both instances that it 'should not be given undue weight.'17 In turn, it is notable that the language of reintegration, reconciliation and restoration is emphasised in the context of the aims of sentencing in three sentencing decisions; sentencing should be conducive to acknowledging the harm to victims and promoting reconciliation. ${ }^{118}$ However, what is most striking in comparisons to ICTY sentencing decisions, is the substantial space given to the views of victims, including the Legal Representatives of Victims, who are voicing arguments not just regarding the factual findings of the case in the judgments, but also regarding sentencing decisions; for example commenting on the presence of aggravating circumstances ${ }^{119}$ or on the sincerity of remorse. ${ }^{120}$ Even with a relatively small number of sentencing decisions at hand, it is indisputable that, in contrast to the ICTY, victims and the aggrieved society at large, take a more prominent place within the lengthy sentencing considerations in the judgments of the ICC. This is particularly evident in the ability of ICC judges to impose reparations on the convicted perpetrators; a convicted person may be ordered to provide financial compensation, rehabilitation measures, or symbolic gestures as reparation to individuals or in a collective manner. ${ }^{121}$ In contrast, the ICTY does not award compensation; though the ICTY RPE provide for restitution of property and compensation

115 Katanga, Decision on Sentence pursuant to Article 76 of the Statute, supra note 113, para. 144.

116 ICC, Prosecutor v. Ntaganda, Case No. ICC-01/04-02/o6, Trial Chamber, Sentencing judgment, 7 November 2019, para. 12; Bemba, Decision on Sentence pursuant to Article 76 of the Statute, supra note 112, para. 11.

117 Ntaganda, Sentencing judgment, supra note 116, para 10; Bemba, Decision on Sentence pursuant to Article 76 of the Statute, supra note 112, para. 11.

118 Al Mahdi, Judgment and Sentence, supra note 112, para. 67. Bemba, Decision on Sentence pursuant to Article 76 of the Statute, supra note 112, para. 11; Katanga, Decision on Sentence pursuant to Article 76 of the Statute, supra note 113, para. 38 .

119 Katanga, Decision on Sentence pursuant to Article 76 of the Statute, supra note 113, para 11.

$120 \quad$ Ibid., para 118.

121 ICC Statute, Art. 75(1): 'The Court shall establish principles relating to reparations to, or in respect of, victims, including restitution, compensation and rehabilitation'. ICC RPE, Rule 97(1): 'Taking into account the scope and extent of any damage, loss or injury, the Court may award reparations on an individualized basis or, where it deems it appropriate, on a collective basis or both'. ICC RPE, Rule 218(3). 
through national mechanisms, ${ }^{122}$ this is not a topic of discussion in the judgments.

It is apparent that the ICC sentencing decisions emphasise the notion of reconciliation and reintegration of the convicted person over notions of rehabilitation. This is also remarkably evident in Al Mahdi, where the accused's guilty plea (the only guilty plea entered at the ICC thus far) and his expressions of remorse are considered not in light of his personal path of rehabilitation, but in the context of his reintegration into society and the furtherance of peace and reconciliation in the community through acknowledging the harm suffered by victims. ${ }^{123}$

While rehabilitation of the convicted person still exists as a sentencing aim at the ICC in theory, in practice, however, the purpose of sentencing has shifted towards the harmed communities. While in the ICTY judgments, rehabilitation is also sometimes described along the lines of reintegration of the convicted person, reintegration appears to take comparatively more prominence in the ICC sentencing decisions where it is associated with notions of reconciliation. This evolution of the conceptualisation of rehabilitation as a sentencing aim is also evident in the Al Mahdi reparation order, where rehabilitation is not considered as perpetrator-focused but in the context of 'restoring the victims and their communities to their former condition. Rehabilitation may include, for instance, economic development or social, medical or legal services'. ${ }^{124}$ For instance, in the case of $A l M a h d i$, the Trial Chamber stated that, collective reparations could comprise educational programmes, resettlement programmes, microcredit programmes, ${ }^{125}$ as well as symbolic measures, such as commemorative services. ${ }^{126}$ In this sense, rehabilitation here is re-conceptualised to encompass the restoration and reconstruction of the communities that have been harmed - to repair some of the damage caused by the hostilities, or in the form of a symbolic act to acknowledge the harm suffered. This is in keeping with the ICC sentencing decisions that highlight the elevated role of victims and the harmed community, not just in according reparations, but also in the very decisions vis-á-vis the sentencing of perpetrators.

\footnotetext{
122 ICTY RPE, Rules 105 and 106.

123 Al Mahdi, Judgment and Sentence, supra note 112, para. 67.

124 ICC, Prosecutor v. Al Mahdi, Case No. ICC-01/12-01/15, Trial Chamber, Reparations Order, 17 August 2017, para. 48.

125 Ibid., para. 83 .

126 Ibid., para. 90.
} 


\section{The Concept of Rehabilitation within Early Release Decisions of the Icc}

In contrast to the ICTY, comparatively more guidance on this process is found in the positive law and more factors are to be taken into account when deciding on sentence reduction. Among the factors set out in the RPE, ${ }^{127}$ the word 'rehabilitation' does not feature - instead resocialisation is the focus. Only two persons convicted by the ICc have been eligible to be considered for early release thus far (Thomas Lubanga Dyilo and Germain Katanga). In accordance with the ICC sentencing decisions, the language in these (few) early release decisions is one of resocialisation, reintegration and resettlement. It may be noted that, in contrast to the ICTY, crime gravity is not taken into consideration in the context of sentence reviews, as it has already been considered in the determination of sentence. ${ }^{28}$ Conduct in detention is also considered here, ${ }^{129}$ and as in the ICTY early release decisions, is counted as predictive of successful future reintegration. However, unlike at the ICTY where conduct in detention is key in determining whether or not early release is granted and is described in detail, here it is emphasised that this factor should not be determinative. ${ }^{130}$

While lack of remorse or responsibility for the crimes is occasionally a factor discussed in the early release decisions of the ICTY, it is a prominent factor in the ICC sentence reviews. ${ }^{131}$ At the ICTY, the notions of remorse and acceptance of responsibility are conflated at times and an abstract acknowledgment of crimes having been committed without recognising any personal responsibility is accepted as sufficient signs of rehabilitation. In contrast, within the ICC early release decisions, the assessment of remorse appears to be more

127 ICC RPE, Rule 223 contains the following criteria: '(a) The conduct of the sentenced person while in detention, which shows a genuine dissociation from his or her crime; (b) The prospect of the resocialization and successful resettlement of the sentenced person; (c) Whether the early release of the sentenced person would give rise to significant social instability; (d) Any significant action taken by the sentenced person for the benefit of the victims as well as any impact on the victims and their families as a result of the early release; (e) Individual circumstances of the sentenced person, including a worsening state of physical or mental health or advanced age'.

128 ICC, Prosecutor v. Lubanga, Case No. ICC-01/04-01/o6, Appeals Chamber, Decision on the Review Concerning Reduction of Sentence of Mr Thomas Lubanga Dyilo, 22 September 2015, para. 24.

129 Ibid., paras. 41-42; ICC, Prosecutor v. Katanga, Case No. ICC-01/04-01/07, Appeals Chamber, Decision on the Review Concerning Reduction of Sentence of Mr Germain Katanga, 13 November 2015, para. 38 .

130 Lubanga, Decision on the Review Concerning Reduction of Sentence of Mr Thomas Lubanga Dyilo, supra note 128 , para. 45 .

131 See also ICC RPE, Rule 223(a). 
scrupulous. ${ }^{132}$ In Lubanga's first sentence review, the Panel noted that, 'there is a difference between a person expressing opposition to a particular criminal act in the abstract and that person accepting responsibility and expressing remorse for having committed those criminal acts (...) Mr Lubanga expressed remorse (...) but did not acknowledge his own culpability'.133 This sentence review application was rejected, as was Lubanga's second sentence review application, in part because his demonstration of remorse has not been found to be sufficient - notably, despite Lubanga's participation in reparation proceedings.

The comparatively prominent role of victims in the ICC sentencing decisions is echoed in the ICC early release decisions that contain reference to the victims' opinions regarding the convicted person's responsibility for the crimes $^{134}$ and whether and how his release would affect the victims, ${ }^{135}$ as well as the reconciliation process in the communities. ${ }^{136}$ For example, in Lubanga's first sentence review, the Panel acknowledged the victims' 'fear that his release and return in the region would give rise to tensions between communities (...) rise to the resumption of the armed conflict and potentially to new war crimes. ${ }^{137}$ Since it is also possible for the ICC Trial Chamber to impose reparations on the convicted person, whether any reparation proceedings have taken place, whether compensation has been paid, and if so, whether this has been deemed a significant action by the victims, are also subject in the early release decisions. ${ }^{138}$ In this sense, there is a coherence between the ICC sentencing decisions that emphasise reconciliation as a purpose of sentencing, and the early release decisions that consider whether steps towards reconciliation have been taken and the impact release will have on reconciliation.

132 Katanga, Decision on the Review Concerning Reduction of Sentence of Mr Germain Katanga, supra note 129, para. $5^{0 .}$

133 Lubanga, Decision on the Review Concerning Reduction of Sentence of Mr Thomas Lubanga Dyilo, supra note 128, para. 46.

134 Ibid., para. 44.

135 Katanga, Decision on the Review Concerning Reduction of Sentence of Mr Germain Katanga, supra note 129, para. 104.

136 Lubanga, Decision on the Review Concerning Reduction of Sentence of Mr Thomas Lubanga Dyilo, supra note 128, para. 51 .

137 Ibid., para. 62; see also, Katanga, Decision on the Review Concerning Reduction of Senence of Mr Germain Katanga, supra note 129, paras. 63, 76 .

138 ICC, Prosecutor v. Lubanga, Case No. ICC-01/04-01/o6, Appeals Chamber, Second Decision on the Review Concerning Reduction of Sentence of Mr Thomas Lubanga Dyilo, 3 November 2017, para. 43; Katanga, Decision on the Review Concerning Reduction of Sentence of Mr Germain Katanga, supra note 129, para. 84. 
As outlined in this article, there is considerable incoherence in the conceptualisation of rehabilitation, both within the ICTY as well as between the ICTY and the ICC. At the ICTY, a prominent discrepancy exists in terms of the conceptualisation of rehabilitation across the judgments and the early release decisions. It is abundantly clear that in the judgments, rehabilitation is considered a negligible purpose of punishment, subordinate to deterrence and retribution. Yet, the achievement of rehabilitation is later evaluated when deciding on early release. Early release clearly requires evidence of successful of rehabilitation (although the evidence may consist of an arcane assortment of factors), and only in rare cases does a lack of rehabilitation still lead to early release being granted. It is a profound paradox that, in spite of scepticism whether imprisonment can have a rehabilitative effect at all, after years of imprisonment, it is expected that convicts can demonstrate some vaguely described manifestations of rehabilitation as evidence should they wish to be granted early release.

The concept of rehabilitation has undergone some transformation within international criminal law, spanning from the case-law of the ICTY to the current practice of the ICC. In comparing the sentencing and early release decisions of the ICTY with those of the ICC, it becomes evident that the focus has shifted from rehabilitating individual perpetrators to reconciling and repairing communities. At the ICC, the purpose of sentencing - the aim of rehabilitation included - encompasses the views and needs of the victims and the harmed societies to a substantial degree, compared to the ICTY. To the extent that rehabilitation is even mentioned at the ICC, it is placed in the context of reconciliation, of rehabilitating victims and communities, a departure from the conceptualisation at the ICTY. This seems to be accompanied by an acknowledgment at the ICC that, in the absence of any meaningful evidence-based rehabilitation programmes for perpetrators of international crimes, incarceration will not automatically rehabilitate the convicted person and facilitate their reintegration; mirroring what some ICTY judgments have suggested. Perhaps an attempt to resolve the internal contradiction concerning the status of rehabilitation that is apparent within the judgments and early release decisions of the ICTY, has been to shift focus from the individual's potential for rehabilitation or recidivism, to establishing peace and security among the affected communities, through reconciliation and restitution. This is highlighted by the Rome Statue providing for a more extensive role for victims and their interests, compared to the Tribunals' Statutes, as well as the comparatively heightened emphasis of the ICC early release decisions on the sincerity of the 
perpetrators' remorse and acceptance of personal responsibility, which is seen as being directly connected to reconciliation efforts.

Generally speaking, rehabilitation has a trivial status both within the ICTY and ICC. Rehabilitation as a sentencing aim might have a negligible role within the judgments of the ICTY; however, when discussed in the ICTY early release decisions, it is done so solely with reference to the prevention of recidivism and the promotion of social reintegration of the perpetrators. At the ICC, the role of rehabilitation has further diminished, with rehabilitation almost disappearing from the sentencing and early release decisions. While reintegration of the perpetrator is tied to the notion of rehabilitation at the ICTY, at the ICC there is a sense that reintegration of the perpetrator must be accompanied by reconciliation of the affected communities; meaning that reintegration is intertwined with notions of reparations and compensation. 